\title{
STUDY OF PREVALENCE OF IRON DEFICIENCY OF ANEMIA IN SCHOOL GOING CHILDREN IN RURAL INDIA
}

\author{
Vidya P. Paranjape ${ }^{1}$
}

\section{HOW TO CITE THIS ARTICLE:}

Vidya P. Paranjape. "Study of Prevalence of Iron Deficiency of Anemia in School going Children in Rural India". Journal of Evolution of Medical and Dental Sciences 2014; Vol. 3, Issue 09, March 3; Page: 2228-2235,

DOI: $10.14260 /$ jemds/2014/2131

BACKGROUND: Micro nutritional deficiencies are common in developing countries like India. Nutritional deficiency anemia is more prevalent in children and young adolescent male and females. The objective of present study was to determine the prevalence of Iron deficiency anemia in children age group 8 - 12 years in our locality. AIM: to estimate the prevalence of IDA in Bhojapur, Taluka Sinnar of Maharashtra. METHODS: this Cross Sectional study was conducted in school going children of Bhojapur, Taluka Sinnar of Maharashtra, age group 8 - 12 year boys and girls. Hemoglobin, Serum Ferritin, Total Iron Binding Capacity [TIBC] and Transferrin levels were analyzed. RESULTS: 185 males and 174 female school going children were examined, IDA was prevalent in $58.9 \%$ of males and $63.2 \%$ in females, there was significant decrease in parameters of Hemoglobin, Serum Ferritin and Transferrin saturation and increase in Total Iron Binding Capacity in this group of population indicating prevalence of the Iron deficiency. CONCLUSIONS: within limitations of the present study it was found that Iron deficiency anemia was common in children in rural India. IDA was slightly more prevalent in girls of the same age group as compared to boys. Lower socioeconomic status was linked with decreased Hemoglobin levels probably due to nutritional deficiencies. This calls for a comprehensive micro nutritional policy in addition to food security to address the problem.

KEYWORDS: [IDA] Iron Deficiency Anemia

INTRODUCTION: Anemia (from the ancient Greek, anemia, meaning 'lack of blood') is defined by a decrease in the total amount of hemoglobin or the number of red blood cells. Iron deficiency anemia is a form of anemia due to the lack of sufficient iron to form normal red blood cells. Iron deficiency anemia is typically caused by inadequate intake of iron, chronic blood loss, or a combination of both. It is the most common cause of anemia in the world ${ }^{1}$. Iron deficiency results in anemia, impaired neurobehavioral performance, and decreased physical work capacity. In iron deficiency there are no mobilizable Iron stores and in which signs of a compromised supply of iron to the tissues including the erythron are noted. The more severe stage of iron deficiency is associated with anemia. Because anemia is most common indicator to screen iron deficiency the terms anemia and iron deficiency anemia are sometimes used interchangeably. ${ }^{2}$

Despite considerable economic and scientific advancement world's quarter of population is anemic highest prevalence of anemia $47.4 \%$ is among the preschool children ${ }^{3}$. IDA affects $43 \%$ of preschool children all over the world, especially in developing countries, which present prevalence rates four times higher than those found in industrialized countries. This high prevalence is associated with poor sanitation conditions, low socioeconomic conditions and high morbidity among infants ${ }^{4}$. The third National Family Health Survey (NFHS) 2005-2006 revealed that at least 80\% of Indian children aged 12 to 23 months were anemic 5 . Anemia was especially prevalent among rural children, the prevalence of anemia in India between 2000 and 2005 increased from $75.3 \%$ to $80.9 \%$ 
in children aged 6 to 36 months.5, 6 Infants, children and adolescents require additional iron due to demands of body growth, lower dietary intake of iron. During the last two trimesters of pregnancy, daily iron requirement increases to 5-6mg.7,8

Iron Metabolism: Element Iron exists basically in two forms the ferrous form $\left(\mathrm{Fe}^{2+}\right)$ and the Ferric form $\left(\mathrm{Fe}^{3+}\right)$. It is an important trace element in human body. The total body stores of iron ranges from 3 - 5gm of the total content of the body Iron partly is used for metabolic and oxidative functions $(70 \%-80 \%)$, and the rest is stored in storage form in the liver, spleen and bone marrow as ferritin and hemosiderin (20-30\%). More than $65 \%$ of the iron content is found in hemoglobin, whose major function is to transport oxygen and carbon dioxide. In hemoglobin, the iron present in ferrous form $\left(\mathrm{Fe}^{2+}\right)$ at the center of the tetrapyrrole core (protoporphyrin IX), forming the heme nucleus. Therefore, iron is essential for the formation of hemoglobin'. In addition, iron is part of the composition of the myoglobin molecule of muscle tissue and acts as an enzyme reaction cofactor in the Krebs cycle, (responsible for the aerobic metabolism of tissues) and in the synthesis of purines, carnitine, collagen and brain neurotransmitters. Iron is also present in the composition of flavoproteins and heme proteins catalase and peroxidase (found in erythrocytes and hepatocytes). These enzymes are responsible for the reduction of the hydrogen peroxide produced in the body ${ }^{10}$. Iron deficiency anemia characterized by microcytic anemia, low serum iron concentration, high total iron binding capacity (TIBC) ${ }^{11}$.

Although several studies have been conducted on prevalence of anemia, the exact demographic statistics and prevalence of this was unknown in our locality and since anemia is so common and if affects the cognitive performance physical working capacity we decided to take up such a study in our locality.

MATERIALS AND METHODS: This cross sectional study was conducted in the sample of population from rural Bhojapur, Taluka Sinnar Maharashtra. The study sample included all school going children aged 8 to 12 years both male and females. The study sample was collected by trained personnel who visited the schools between 9: $00 \mathrm{AM}$ to 11: $00 \mathrm{AM}$ the collected samples were stored in standard conditions and transported to SMBT Institute Medical Sciences and research Centre, Nandihills, Dhamangaon-Ghoti, Tal. Igatpuri, Dept. of Hematology for analysis. The sample size was $(\mathrm{n}=359)$ of which 185 (51.53\%) were male children and 174 (48.46\%) were females

\section{Inclusion criteria:}

1. Rural school going healthy children $8-12$ years

2. No history of blood transfusion.

3. No history of recent malaria, jaundice, or other haematological disorders

4. No history of recent medications.

\section{Exclusion criteria:}

1. Those who does not fulfil any inclusion criteria

2. Individuals or guardians unwilling to participate voluntarily in the study. 
Laboratory Analysis: $5 \mathrm{ml}$ of venous blood was collected from sterile venipuncture by trained personnel in 500micro liter tubes filled with EDTA K2. All the lab analysis was done within six hours of collection of sample. The Hemoglobin was estimated with autoanalyzer Sysmex Kobe Japan. Serum was separated with centrifuge and serum ferritin was estimated using chemiluminescence Immunoassay using Abbott Architect ${ }^{\circledR}$ two step microparticle immunoassay. Serum Iron and TIBC were estimated by Iron and TIBC kit in semiautoanalyzer, (Erba Chem 5plus) which uses Ferrozine method ${ }^{12}$ Transferrin saturation was calculated as Serum iron $\times 100 /$ TIBC 13 .

Statistical Analysis: Collected data was entered in the Microsoft Word Excel Sheet 2007 version and the data obtained was analyzed using the SPSS (Statistical Package for the Social Sciences) 17 Version.

RESULTS: Table 1 show the age and sex wise distribution of males and female children included in the study.

\begin{tabular}{|c|c|c|c|c|}
\hline Age Group years & Males & $\mathbf{\%}$ & Females & $\mathbf{\%}$ \\
\hline $8.0-9.0$ & 21 & 11.35 & 15 & 8.62 \\
\hline $9.1-10$ & 35 & 18.92 & 29 & 16.67 \\
\hline $10.1-11$ & 59 & 31.89 & 43 & 24.71 \\
\hline $11.1-12$ & 70 & 37.84 & 87 & 50.0 \\
\hline Total & $\mathbf{1 8 5}$ & $\mathbf{1 0 0}$ & $\mathbf{1 7 4}$ & $\mathbf{1 0 0}$ \\
\hline
\end{tabular}

Table 1: Showing the age and sex wise distribution of children in study

Table 2 shows sex wise distribution of normal and Iron Deficiency Anemia in males and females where as in males $58.9 \%$ were found to be suffering from IDA in the females of $63.2 \%$ were found to be suffering from IDA.

\begin{tabular}{|c|c|c|c|c|c|}
\hline Sex & Total (n) & Normal & $\mathbf{\%}$ & IDA & $\mathbf{\%}$ \\
\hline Males & 185 & 76 & 41.08 & 109 & 58.9 \\
\hline Females & 174 & 64 & 36.8 & 110 & 63.2 \\
\hline
\end{tabular}

\section{Table 2: Sex wise distribution of Normal and Iron Deficiency Anemia}

Table 3 shows age wise distribution of number of male children, hemoglobin levels of $<11.4$ gm. / dl were classified as anemic those with hemoglobin more than $11.5 \mathrm{gm}$. / $\mathrm{dl}$ were classified as non-anemic for children of 8 -12 years age ${ }^{14}$. A total of 109 males $58.9 \%$ were having hemoglobin less than $11.4 \mathrm{gm} . / \mathrm{dl}$ indicating anemia. While 16 (8.6\%) having Hb levels less than $8 \mathrm{gm} . / \mathrm{dl}$ indicating severe anemia and 34 (18.38\%) having Hemoglobin levels ranging from $8-10 \mathrm{gm} / \mathrm{dl}$ indicating moderate anemia and 59 (31.89\%) had hemoglobin levels ranging from $10.1-11.4 \mathrm{gm} . / \mathrm{dl}$ indicating mild anemia. 


\begin{tabular}{|c|c|c|c|c|c|}
\hline Age group & No of children & $\mathbf{<} \mathbf{~ g m . / d l}$ & $\mathbf{8 . 1} \mathbf{- 1 0 . 0} \mathbf{~ g m . / d l}$ & $\mathbf{1 0 . 1} \mathbf{- 1 1 . 4} \mathbf{~ g m . / d l}$ & $>\mathbf{1 1 . 5} \mathbf{g m} . / \mathbf{d l}$ \\
\hline $8-9.0$ & 21 & 6 & 4 & 2 & 10 \\
\hline $9.1-10.0$ & 35 & 2 & 7 & 9 & 17 \\
\hline $10.1-11.0$ & 59 & 3 & 14 & 29 & 13 \\
\hline $11.1-12.0$ & 70 & 5 & 9 & 20 & 36 \\
\hline total & $\mathbf{1 8 5}$ & $\mathbf{1 6}$ & $\mathbf{3 4}$ & $\mathbf{5 9}$ & $\mathbf{7 6}$ \\
\hline
\end{tabular}

Table 3: Hemoglobin distributions in Male children of various age groups

Table 4 shows the female children of various age groups with hemoglobin concentration of the total 174 children about 63.2\% were detected with anemia, 56 (32.18\%) children had Hemoglobin levels less than $8 \mathrm{gm}$. /dl indicating severe anemia and about 34 (19.54\%) children had moderate anemia and 20 (11.49\%) had mild anemia and only 64 (36.4\%) were having their hemoglobin concentration of greater than $11.5 \mathrm{gm}$. / dl were classified as non-anemic.

\begin{tabular}{|c|c|c|c|c|c|}
\hline Age group & No of children & < 8 gm./dl & $\mathbf{8 . 1} \mathbf{~ 1 0 . 0 ~ g m . / d l ~}$ & $\mathbf{1 0 . 1} \mathbf{- 1 1 . 4} \mathbf{~ g m . / d l}$ & > 11.5 gm./dl \\
\hline $8-9.0$ & 15 & 4 & 3 & 3 & 5 \\
\hline $9.1-10.0$ & 41 & 18 & 8 & 2 & 13 \\
\hline $10.1-11.0$ & 39 & 11 & 7 & 4 & 17 \\
\hline $11.1-12.0$ & 79 & 23 & 16 & 11 & 29 \\
\hline total & $\mathbf{1 7 4}$ & $\mathbf{5 6}$ & $\mathbf{3 4}$ & $\mathbf{2 0}$ & $\mathbf{6 4}$ \\
\hline
\end{tabular}

Table 4: Hemoglobin distributions in female children of various age groups

Table 5 shows the serum ferritin concentration in $\mathrm{ng} / \mathrm{ml}$ for normal males and females. Serum ferritin in males was 90.3-110.5 mean value of 100.4 the calculated p value was $>0.1$ not significant in normal children. For Iron Deficiency Anemia group males the values ranged from 5.010.5 in males and mean value of 7.75 with calculated $p$ value was $<0.05$ was significant and for females in normal group serum ferritin ranged from $78.0-118.4 \mathrm{ng} / \mathrm{ml}$ and calculated $\mathrm{p}$ was $>0.1$ and non-significant. The serum ferritin concentration in females of IDA group the values ranged from 4.9 to $9.1 \mathrm{ng} / \mathrm{ml}$ mean was 7.0 and $\mathrm{p}$ value was $<0.001$ was significant.

\begin{tabular}{|c|c|c|c|c|c|c|c|}
\hline sex & $\begin{array}{c}\text { Number of } \\
\text { children } \\
\text { Normal }\end{array}$ & $\begin{array}{c}\text { Serum ferritin } \\
\mathbf{n g} / \mathbf{m l} \\
{[\mathbf{C I}-\mathbf{9 5 \%}}\end{array}$ & Mean \pm SD & $\begin{array}{c}\text { Number of } \\
\text { children } \\
{[\mathbf{I D A}]}\end{array}$ & $\begin{array}{c}\text { Serum ferritin } \\
\mathbf{n g} / \mathbf{m l} \\
{[\mathbf{C I}-\mathbf{9 5 \%}}\end{array}$ & Mean \pm SD & P value \\
\hline males & $76(\mathrm{n}=185)$ & $90.3-110.5$ & $100.4 \pm 6.9$ & 109 & $5.0-10.5$ & $7.75 \pm 2.35$ & $<0.05 *$ \\
\hline females & $64(\mathrm{n}=174)$ & $78.0-118.4$ & $98.2 \pm 5.71$ & 110 & $4.9-9.1$ & $7.0 \pm 1.9$ & $<0.001^{*}$ \\
\hline
\end{tabular}

Table 5: Serum Ferritin ng/ml in Normal and Iron Deficiency Anemia [IDA] males and females

* Significant

Table 6 shows the Total Iron Binding Capacity TIBC in normal males and females compared with Iron Deficiency anemia group the TIBC values in normal males ranged from $285-360 \mu \mathrm{g} / \mathrm{dl}$ for IDA group the mean values was $390-460$ and the calculated $p$ value was $<0.01$ was significant and 
for females of normal group the TIBC ranged from $256-350 \mu \mathrm{g} / \mathrm{dl}$ and for IDA of the same group the values of TIBC ranged from $380-442 \mu \mathrm{g} / \mathrm{dl}$ the calculated p values was $<0.001$ which is significant.

\begin{tabular}{|c|c|c|c|c|c|c|c|}
\hline sex & $\begin{array}{c}\text { Number of } \\
\text { children } \\
\text { Normal }\end{array}$ & $\begin{array}{c}\text { TIBC } \\
\boldsymbol{\mu g} / \mathbf{d l} \\
{[\mathbf{C I}-\mathbf{9 5 \%}}\end{array}$ & Mean \pm SD & $\begin{array}{c}\text { Number of } \\
\text { children } \\
{[\text { IDA] }}\end{array}$ & $\begin{array}{c}\text { TIBC } \boldsymbol{\mu g} / \mathbf{d l} \\
{[\mathbf{C I}-\mathbf{9 5 \%}}\end{array}$ & $\mathbf{M e a n} \pm$ SD & P value \\
\hline males & $76(\mathrm{n}=185)$ & $285-360$ & $322.5 \pm 18.5$ & 109 & $390-460$ & $425 \pm 20.54$ & $<0.01^{*}$ \\
\hline females & $64(\mathrm{n}=174)$ & $256-350$ & $303 \pm 14.0$ & 110 & $380-442$ & $411 \pm 17.6$ & $<0.001^{*}$ \\
\hline
\end{tabular}

\section{Table 6: Total Iron Binding Capacity [TIBC] in Normal and}

Iron Deficiency Anemia [IDA] males and females

* Significant

Table 7 shows the Transferrin saturation in normal males and females compared with Iron Deficiency anemia group the Transferrin saturation values in normal males ranged from $27-45 \%$ for IDA group the mean values was $6-17 \%$ and the calculated $p$ value was $<0.01$ was significant and for females of normal group the Transferrin saturation ranged from 30-40 and for IDA of the same group the values of Transferrin saturation ranged from $5-12$ the calculated $p$ values was $<0.001$ which is significant.

\begin{tabular}{|c|c|c|c|c|c|c|c|}
\hline sex & $\begin{array}{c}\text { Number of } \\
\text { children } \\
\text { Normal }\end{array}$ & $\begin{array}{c}\text { Transferrin } \\
\text { Saturation \% } \\
{[\text { CI - 95\%] }}\end{array}$ & Mean \pm SD & $\begin{array}{c}\text { Number of } \\
\text { children } \\
{[\text { IDA] }}\end{array}$ & $\begin{array}{c}\text { Transferrin } \\
\text { Saturation \% } \\
{[\text { CI - 95\%] }}\end{array}$ & Mean \pm SD & P value \\
\hline males & $76(\mathrm{n}=185)$ & $27-45$ & $36 \pm 6$ & 109 & $6-17$ & $11.5 \pm 2.7$ & $<0.01^{*}$ \\
\hline females & $64(\mathrm{n}=174)$ & $30-40$ & $35 \pm 5$ & 110 & $5-12$ & $8.5 \pm 2.2$ & $<0.001^{*}$ \\
\hline \multicolumn{7}{|c|}{ Table 7: Transferrin saturation \% in Normal and } \\
Iron Deficiency Anemia [IDA] males and females
\end{tabular}

* Significant

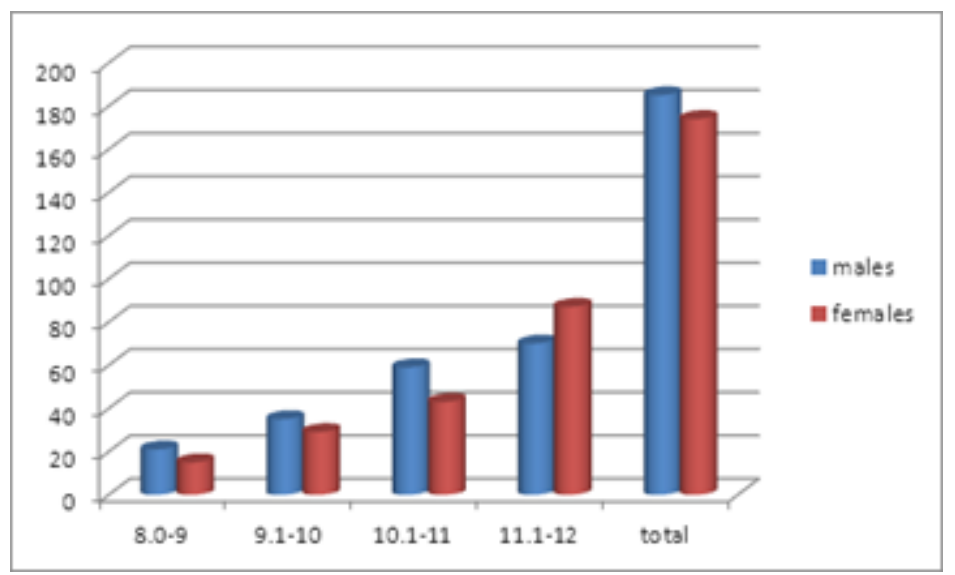

Fig. 1: Age and Sex wise distribution of study population 


\section{ORIGINAL ARTICLE}

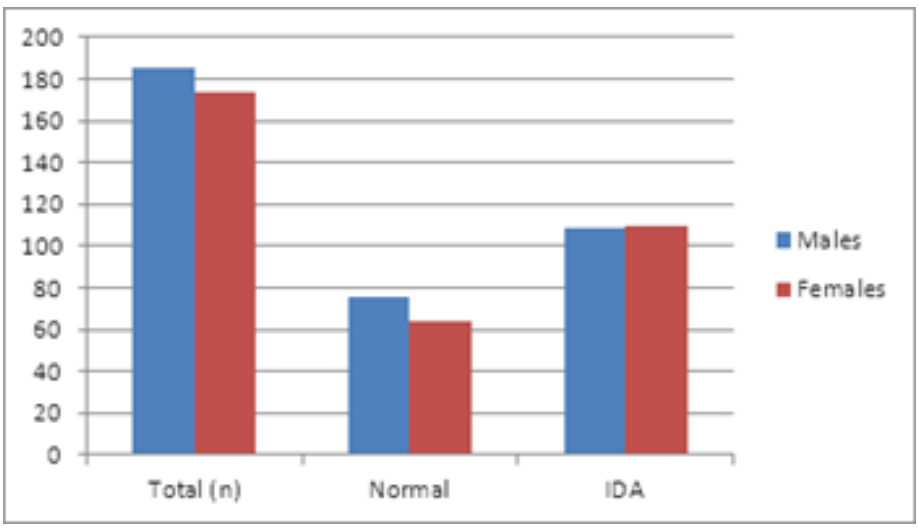

Fig. 2: Total distribution of cases Normal and Iron Deficiency Anemia IDA

DISCUSSION: Iron Deficiency Anemia affects 43\% of preschool children all over the world especially in developing countries, in which the present prevalence rates of four times higher than those found in industrialized countries, this high prevalence is associated with poor sanitary conditions and low socio economic status and high morbidity among infants 15 . In our study we found an overall prevalence of IDA in our population was $61 \%$. There was slight difference in prevalence of IDA among males and females while in former the percentage was 58.9 in latter it was $63.2 \%$ and also the number of individuals suffering from severe anemia was different in males about $8.6 \%$ individuals had severe anemia and in females $32.18 \%$ were severely anemic. This could probably be due to the fact that in our population about $87(n=174) 50.0 \%$ of females were older than 11 years and some of them may have reached menarche.

In a similar study by Verma $\mathrm{M}$ et al; reported the overall prevalence of anemia of $57.5 \%$ with girls having higher prevalence of anemia and more menarchal girls were anemic as compared to those who did not attend menarche ${ }^{16}$. Vasanthi et al. assessed the iron nutritional status among 312 rural school girls of Delhi ${ }^{17}$. The prevalence of anemia ( $\mathrm{Hb}<12 \mathrm{~g} / \mathrm{dl}$ ) was $28 \%$ in girls who had attained menarche and $22 \%$ in girls who had not attained menarche. In another study by Sheshadri S among 1, 500 rural girls (10-19 yrs.) from 10 villages in Gujarat, the prevalence of anemia ( $\mathrm{Hb}<12$ $\mathrm{g} / \mathrm{dl}$ ) was reported to be $60 \%{ }^{18}$. In another study in Delhi, anemia occurred in $46.6 \%$ of high socioeconomic and $56 \%$ of lower middle socio-economic class girls ${ }^{19}$. In a similar study by Toteja et al in adolescent females in 16 districts of 11states across India found higher prevalence of anemia of 90.1\%.

We also found that serum ferritin levels were decreased significantly in both males and females in the IDA group. There is also an increase in Serum Total Iron Binding Capacity [TIBC], which are the primary indicators of Iron Deficiency Anemia. Serum ferritin is the most useful index in public health context as reported by $\mathrm{WHO}^{20}$. Lower serum ferritin levels in our population could be due to poor nutrition, lower socioeconomic status and inadequate dietary intake. Lower transferrin saturation along with low ferritin is an indicator of iron deficiency and complete exhaustion of iron stores are considered when ferritin levels fall below $12 \mathrm{ng} / \mathrm{ml}$ and Transferrin Saturation is $<15 \%{ }^{21}$.

CONCLUSIONS: within limitations of the present study it was found that Iron deficiency anemia IDA was common in children in rural India. IDA was slightly more prevalent in girls of the same age group 
as compared to boys. Lower socioeconomic status was linked with decreased Hemoglobin levels probably due to nutritional deficiencies. In 1995, the Government of India launched the National Program of Nutritional Support to Primary Education NSPE. Though the primary objective of this program was to improve school attendance, it is likely to have a major impact on nutritional status of school children. However much more needs to be done including forming a comprehensive micro nutritional policy in addition to food security to address the problem.

\section{REFERENCES:}

1. Clark S F. Iron deficiency anemia diagnosis and management- current opinion. Gastroenterology 2009; 25; 122-28.

2. World Health Organization. Iron deficiency anaemia: assessment, prevention and control. A guide for program managers. WHO/NHD/01.3. Geneva, Switzerland: World Health Organization, 2001; pg 3-4.

3. Benoist B, McLean E et al. Worldwide Prevalence of Anaemia 1993-2005. Geneva, Switzerland: World Health Organization; 2008. Available at: whqlibdoc.who.int/publications/2008/9789241596657_eng.pdf. Accessed Nov 20, 2013

4. Finch CA. Iron nutrition: food and nutrition in health and disease. Ann NY Acad Sci 1977; 300:221.

5. International Institute for Population Sciences and Macro International. National Family Health Survey (NFHS-3), 2005-2006: Key Findings. Mumbai, India: International Institute for Population Sciences; 2007. Available at: www.measuredhs.com/pubs/pdf/SR128/SR128.pdf. Accessed Nov 20, 2010

6. International Institute for Population Sciences. The Second National Family Health Survey (NFHS-2), 1998-1999. Mumbai, India: International Institute for Population Sciences (IIPS) and ORC Macro; 2000. Available at: www.nfhsindia.org/india2.html. Accessed Nov 20, 2013.

7. WHO. Techn. Rep. Ser. No. 405(1968).

8. Kumar P. Hematological disease. In: Kumar P, Clark M (editors). Kumar \& Clark's Clinical Medicine.7th Ed. Pg.392.

9. De Angelis RC, Ctenas MLB. Bioavailability of iron in infant feeding. Themes of Pediatrics 52, Nestlé Scientific Information Service, 1993.

10. The Bottoni, Ciolette A Schimitz BAS, Campanaro CM, Accioly and Cuvello LCF. Iron deficiency anemia. Rev Paul Pediatr 1997; 15: 127-34.

11. Worwood M. Serum ferritin. CRC Critical Reviews in Clinical Laboratory Sciences, 1979, 10:171-204.

12. Siedel J, Wahlefeld A. W. \& Ziegenhorn J. A new iron ferrozine-reagent without deproteinisation. Clin. Chem 1984; 30:975.

13. Sharma D, Mathur R, Singh P. Iron metabolism: A Review. Indian Journal of Clinical Biochemistry, 8(2): 80-101, (1993).

14. Nutritional Anaemias. Report of a WHO Scientific Group. Geneva, World Health Organization, 1968 (WHO Technical Report Series, No. 405).

15. Finch CA. Iron nutrition, Food and Nutrition in health and disease. Ann NY Acad Sci 1977; 300; 22. 


\section{ORIGINAL ARTICLE}

16. Verma M, Chhatwal J. Prevalence of anemia among urban school children of Punjab. Indian Pediatr 35(12):1181-6 Dec 1998.

17. Vasanthi G, Pawashe AB, H Susie, T Sujatha, Raman L. Iron nutritional status of adolescent girls from rural area and urban slum. Indian Pediatr 1994; 31: 127-132.

18. Sheshadri S. Nutritional Anemia in South Asia. In: Malnutrition in South Asia: A Regional Profile Ed. Gillespie S. Katmandu, UNICEF Regional Office for South Asia 1997; pp 75-124.

19. Kapoor G, Aneja S. Nutritional disorders in adolescent girls. Indian Pediatr 1992; 29: 969-973.

20. WHO and Center for Disease Control and prevention; assessing Iron status of populations; including literature review report of joint WHO and Centre for Disease Control and Prevention technical consultation on assessment of Iron status at the population level Geneva, Switzerland WHO/CDC; 6 -8 April 2004 pg 5.

21. Hussain A, Tayyeb $M$ et al. Serum ferritin an indicator of bone marrow stores in hemolysed patients; Kidney int 152-56 1999.

\section{AUTHORS:}

1. Vidya P. Paranjape

\section{PARTICULARS OF CONTRIBUTORS:}

1. Dean \& HOD, Department of Pediatrics, SMBT Institute of Medical Sciences \& Research Centre.

\section{NAME ADDRESS EMAIL ID OF THE}

\section{CORRESPONDING AUTHOR:}

Dr. Vidya P. Paranjape, Dean \& HOD, Department of Pediatrics, SMBT Institute of Medical Sciences \& Research Centre, Nandihills, Dhamangaon - Ghoti, Tal. Igatpuri, Dist. Nasik.

E-mail: vpparanjape2@gmail.com

Date of Submission: 22/01/2014. Date of Peer Review: 23/01/2014. Date of Acceptance: 05/02/2014. Date of Publishing: 27/02/2014. 